\title{
NR2F6 Gene
}

National Cancer Institute

\section{Source}

National Cancer Institute. NR2F6 Gene. NCI Thesaurus. Code C18385.

This gene is involved in transcriptional regulation and mutations in the gene are associated with the abolishment of transcriptional repression. 